\title{
Toksisitas Akut Ekstrak Albertisia papuana Becc. pada Daphnia magna dan Danio rerio
}

\section{Acute toxicity extract of Albertisia papuana Becc. on Daphnia magna and Danio rerio}

\author{
Hary Nugroho ${ }^{1}$, Marihot Pasaribu ${ }^{2,3}$, Sjarif Ismail ${ }^{2,4 *}$ \\ ${ }^{1}$ Laboratorium Anatomi Fakultas Kedokteran Universitas Mulawarman, Samarinda \\ ${ }^{2}$ Laboratorium Farmakologi Fakultas Kedokteran Universitas Mulawarman, Samarinda \\ ${ }^{3}$ SMF Obstetri dan Ginekologi RSUD Abdul Wahab Sjahranie, Samarinda \\ ${ }^{4}$ Pusat Penelitian Obat dan Kesehatan Masyarakat Lembaga Penelitian dan Pengabdian Kepada Masyarakat \\ Universitas Mulawarman, Samarinda \\ Email: ismail8997@yahoo.com *Penulisuntuk korespondensi
}

\begin{abstract}
Albertisia papuana Becc. (A. papuana) is used by ethnic Dayaks in East Kalimantan as antihypertensive, anti-infective, antipyretic, and cooking flavor essence subtitute. A test of acute toxicity needs to be conducted on Albertisia papuana Becc. (A. papuana) to reveal the data of its acute toxicity which has not been existed before. The objective of this study is to determine the acute toxicity of $A$. papuana leaf extract with Dapnia magna (D. magna) immobilization test and Danio rerio (D. rerio) acute toxicity test. Method: $A$. papuana leaf taken from Kutai Kartanegara Regency, East Kalimantan Province. Maceration is extracted by using ethanol solvents. $D$. magna immobilization test and $D$. rerio acute toxicity test are done with Organisation for Economic Co-operation and Development (OECD) method. The results show that Lethal Concentration $50\left(\mathrm{LC}_{50}\right)$ extract on $D$. magna were $(170 \pm 28) \mathrm{mg} / \mathrm{L}$ for 24 hours and $(45 \pm 9)$ $\mathrm{mg} / \mathrm{L}$ for 48 hours. The $\mathrm{LC}_{50}$ value of extracts on $D$. rerio were $(885+55) \mathrm{mg} / \mathrm{L}$ for 24 hours, $(670+94)$ for 48 hours, $(504+102)$ for 72 hours, and $(393+89)$ for 96 hours. The conclusion of this study is that ethanol extract of $A$. papuana is slightly toxic on $D$. magna, while is practically nontoxic in adult $D$. rerio.
\end{abstract}

Keywords: Albertisia papuana, acute toxicity, $\mathrm{LC}_{50}$, Daphnia magna, Danio rerio.

\begin{abstract}
Abstrak
Albertisia papuana Becc. (A. papuana) digunakan oleh etnis Dayak di Kaltim sebagai obat antihipertensi, antiinfeksi, anti demam, dan bumbu masak pengganti vetsin. Belum adanya data mengenai toksisitas akut pada Albertisia papuana Becc. (A. papuana) menyebabkan perlunya uji toksisitas akut. Tujuan dari peneltian ini adalah untuk mengetahui toksisitas akut pada ekstrak daun A. papuana dengan uji imobilisasi Daphnia magna (D. magna) dan uji toksisitas akut Danio rerio (D. rerio). Metode: Daun A. papuana diambil dari Kabupaten Kutai Kartanegara, Provinsi Kalimantan Timur. Ekstraksi dilakukan secara maserasi dengan pelarut etanol. Uji imobilisasi $D$. magna dan uji toksisitas akut $D$. rerio dilakukan dengan metode OECD (Organisation for Economic Co-operation and Development). Hasil yang didapatkan adalah nilai Lethal Concentration 50 (LC $\left.\mathrm{C}_{50}\right)$ ekstrak pada $D$. magna adalah $(170 \pm 28) \mathrm{mg} / \mathrm{L}$ untuk 24 jam dan $(45+9) \mathrm{mg} / \mathrm{L}$ untuk 48 jam.Nilai $\mathrm{LC}_{50}$ ekstrak pada $D$. rerio adalah $(885+55) \mathrm{mg} / \mathrm{L}$ untuk 24 jam, $(670 \pm 94) \mathrm{mg} / \mathrm{L}$ untuk $48 \mathrm{jam},(504 \pm 102) \mathrm{mg} / \mathrm{L}$ untuk $72 \mathrm{jam}$, dan $(393 \pm 89) \mathrm{mg} / \mathrm{L}$ untuk 96 jam. Simpulan yang diperoleh dari penelitian ini adalah ekstrak etanol $\bar{A}$. papuana sedikit toksik pada $D$. magna sedangkan pada $D$. rerio dewasa bersifat tidak toksik.
\end{abstract}

Kata Kunci: Albentisia papuana, toksisitas akut, $\mathrm{LC}_{50}$, Daphnia magna, Danio rerio. 


\section{Pendahuluan}

Albertisia papuana Becc. (A. papuana) dari keluarga Menispermaceae dikenal dengan nama daun Afa (Dayak Abai dan Lun Dayeh di Kabupaten Malinau, Kalimantan Utara), Bekkai dan Mekai (Dayak Kenyah di Kabupaten Kutai Timur, Kalimantan Timur dan Serawak), Sankang (Dayak di Kalimantan Barat) (Nurbani dan Sumarmiyati, 2015; Lemlit, 2015; Mayasari dkk., 2017; Ismail dkk., 2017). Secara etnobotani, daun ini digunakan sebagai obat (antihipertensi, antiinfeksi dan antidemam), dan bumbu masak pengganti vetsin (Susiarti dan Setyowati, 2005; Lusiana dkk., 2013; Lemlit, 2015; Mayasari dkk., 2017). Daun ini menimbulkan cita rasa umami yang mirip dengan monosodium glutamat (Mayasari dkk., 2017).

Perlu dilakukan penelitian toksisitas pada A. papuana yang digunakan sebagai obat dan bumbu masak sehari-hari. Toksisitas adalah sifat relatif dari suatu zat yang dapat menimbulkan efek merugikan dan berbahaya karena dapat menyebabkan kerusakan yang bersifat struktural ataupun fungsional, bahkan kematian (Frank, 1995). Data yang didapatkan dari hasil uji toksisitas dapat memberikan informasi seberapa besar potensi bahaya yang diujikan dan membantu mengidentifikasi efek samping yang dapat diprediksi jika diujikan pada manusia (Hodgson dan Levi, 2000). Secara umum, pengujian toksisitas berdasarkan lamanya dapat dibagi menjadi uji toksisitas akut, subkronik, dan kronik. Uji toksisitas akut perlu dilakukan terlebih dahulu sebelum dilakukan uji toksisitas lainnya seperti uji toksisitas subakut dan kronik, uji toksisitas reproduksi dan mutagenikkarsinogenesis.

Uji toksisitas akut pada hewan invertebrata seperti pada penggunaan $D$. magna (D. magna) dan Artemia salina (A. salina), dapat digunakan untuk melihat toksisitas suatu zat dan potensi suatu zat sebagai anti kanker. Kedua model hewan yang digunakan untuk tes tersebut mudah dikerjakan, hasil cepat didapatkan, murah dan mempunyai hubungan erat dengan toksisitas akut yang diamati pada mencit dan tikus (Nitulescu dkk., 2013). D. magna mempunyai keunggulan dibandingkan dengan $A$. salina karena larva $D$. magna berukuran lebih besar sehingga lebih mudah diamati, maka kesalahan penghitungan dapat diperkecil (Pankey, 2009). Uji toksisitas dilakukan dengan mengamati efek suatu zat pada hewan uji, dapat berupa kematian hewan uji dan imobilisasi atau ketidakmampuan hewan uji untuk bergerak bebas (immobilisation test), tergantung dari hewan yang diujikan (Frank, 1995). Pada uji imobilisasi akut, berbagai konsentrasi zat yang diujikan akan menghasilkan berbagai tingkat efek toksik yang berkolerasi pada ketidakmampuan berenang hewan uji, yaitu larva D. magna dalam 48 jam paparan yang disajikan dalam nilai $\mathrm{LC}_{50}$. Nilai $\mathrm{LC}_{50}$ adalah konsentrasi yang menimbulkan respon tertentu (kematian atau imobilisasi) pada $50 \%$ hewan uji pada kondisi yang terkendali, semakin kecil nilai $\mathrm{LC}_{50}$ dapat diartikan bahan yang toksik (EPA, 1996). Dari hasil pengujian, nilai $\mathrm{LC}_{50}$ diperoleh melalui perhitungan menggunakan program EPA Probit ver. 1,5 atau program statistik lainnya yang mendukung perhitungan nilai $\mathrm{LC}_{50}$, setelah didapatkan data persen kematian pada beberapa konsentrasi. Hasil uji toksisitas akut pada D. magna dapat digunakan sebagai dasar uji toksisitas lanjutan, yaitu uji reproduksi untuk mengetahui efek teratogenik zat yang diujikan dengan menghitung persentase penetasan telur D. magna karena ia dapat bereproduksi secara aseksual (parthenogenesis) dan dapat menghasilkan larva dua atau tiga hari sekali (Pankey, 2009; OECD, 1992).

Akhir-akhir ini penggunaan Danio rerio (D. rerio) semakin banyak digunakan untuk uji toksisitas akut pada model hewan uji vertebrata. Hewan ini banyak dikembangkan sebagai hewan uji pada penelitian penyakit pada manusia terutama berhubungan dengan keganasan (Berghmans dkk., 2005). Selain itu, D. rerio memiliki beberapa keuntungan seperti mudah didapat dan diamati, memiliki kemiripan DNA yang cukup tinggi dengan manusia dan kesamaan efek toksik pada manusia, sensitif terhadap toksikan sehingga dapat digunakan sebagai bioindikator polutan pada penelitian toksisitas (Rubinstein, 2006; Martínez-Sales dkk., 2015).

Pada penelitian sekarang ini digunakan dua jenis hewan, yang mana D. magna sebagai model hewan invertebrata dan $D$. rerio sebagai model hewan vertebrata untuk dibandingkan 
efek toksik dari ekstrak A. papuana melalui uji toksisitas akut. Hasil penelitian ini digunakan sebagai dasar untuk pemilihan hewan yang lebih sensitif untuk penelitian lebih lanjut ke arah uji embriotoksik.

\section{Metode Penelitian}

\section{Ekstraksi}

Daun A. papuana diambil dari Kabupaten Kutai Kartanegara, Provinsi Kalimantan Timur yang telah diketahui sebelum penelitian dimulai banyak tumbuh tersebut berada karena ditamam oleh suku Dayak untuk bumbu masak. Identifikasi jenis dibantu oleh ahli taksonomi dari Universitas Mulawarman dengan surat hasil diterminasi No. 50/UN17.4.3.08/LL/2016. Surat persetujuan etik dikeluarkan oleh Komisi Etik Penelitian Fakultas Kedokteran Universitas Mulawarman dengan No. 69/KEPKFK/VIII/2018. Daun A. papuana setelah tiba di Laboratorium Farmakologi Fakultas Kedokteran Universitas Mulawarman, dilakukan sortasi, pencucian dengan air mengalir, kemudian ditiriskan lalu dimasukkan dalam lemari pengering dengan suhu $60^{\circ} \mathrm{C}$. Daun $A$. papuana tersebut dibolak-balik setiap harinya dan pada hari ke lima setelah daun menjadi legas digiling menjadi serbuk kasar. Pengujian kadar air pada daun digunakan metode Gravimetri seperti yang dideskripsikan dalam Farmakope Indonesia (1995).

Simplisia dengan kadar air $<10 \%$ seperti yang dipersyaratkan Farmakope Herbal Indonesia dimaserasi dengan pelarut etanol $97 \%$ (Pharmaceutical Grade). Pembuatan ekstrak seperti yang dideskripsikan dalam Farmakope Herbal Indonesia (2008) dengan sedikit modifikasi. Satu bagian serbuk simplisia (465 g) dimasukkan ke botol maserator, lalu ditambahkan 10 bagian pelarut $(10 \mathrm{~L})$. Rendam selama 6 jam dan sekali-sekali diaduk dengan shaker orbital kecepatan 2 rpm selama 5 menit setiap jam. Maserasi dilakukan pada suhu kamar, diamkan selama 18 jam, kemudian maserat dipisahkan dengan kertas saring Whatman. Proses penyaringan diulangi sebanyak dua kali dengan jenis dan jumlah pelarut yang sama. Maserat yang terkumpul dipekatkan dengan vakum rotavapor suhu $50^{\circ} \mathrm{C}$. Ekstrak pekat dikeringkan lebih lanjut dengan dimasukkan dalam desikator berisi silika gel biru, lalu dimasukan dalam oven $50^{\circ} \mathrm{C}$ selama satu minggu, setiap hari silika diganti dengan yang baru. Ekstrak kemudian ditimbang dan diukur kadar airnya seperti yang dideskripsikan oleh AOAC (2006). Rendemen dihitung melalui persamaan: Rendemen $(\%)=(\mathrm{A} /(\mathrm{B} \times(1-$ kadar air)) x $100 \%$. A adalah bobot ekstrak (g) dan $\mathrm{B}$ adalah bobot contoh awal (g). Ekstrak kering disimpan dalam kulkas $-20^{\circ} \mathrm{C}$ sebelum dilakukan penelitian lebih lanjut. Ekstrak juga diuji kadar air dengan metode Gravimetri seperti yang dideskripsikan dalam Farmakope Indonesia (1995).

\section{Uji Toksisitas Akut pada D. magna}

Metode uji toksisitas akut pada ekstrak seperti yang dideskripsikan oleh OECD No. 202 tahun 2004 dengan sedikit modifikasi, D. magna yang digunakan berumur $<24$ jam. Induk $D$. magna diperoleh dari Fakultas Pertanian Universitas Mulawarman, kemudian dikembangbiakkan di Laboratorium Farmakologi Universitas Mulawarman. D. magna yang mengandung telur dimasukkan ke dalam cawan $25 \mathrm{~mL}$ sebanyak 25 buah, setiap cawan berisi dua atau tiga ekor, dan suhu ruangan dipertahankan $18-22^{\circ} \mathrm{C}$. Setiap hari dilakukan pengamatan untuk melihat kemungkinan adanya D. magna yang menetas pada masing-masing cawan. Apabila ada D. magna yang menetas, langsung dipisahkan untuk digunakan dalam penelitian. Pada penelitian ini tidak dibedakan antara jantan dan betina larva $D$. magna seperti pada OECD.

Larva D. Magna sebanyak 10 ekor dimasukkan ke dalam ekstrak dengan berbagai konsentrasi $(10,50,100,250$, dan $500 \mathrm{mg} / \mathrm{L})$ dimasukkan larva $D$. magna sebanyak 10 ekor. Pada penelitian ini, ekstrak dilarutkan dalam DMSO $0,01 \%$ sehingga digunakan pelarut ekstrak sebagai kontrol untuk faktor koreksi. Selanjutnya, dilakukan pengamatan terhadap jumlah D. magna yang tidak bergerak pada 24 jam dan 48 jam. D. magna yang tidak bergerak ini dianggap sudah mati, lalu dihitung nilai $\mathrm{LC}_{50}$ dengan menggunakan program probit. Pengulangan dilakukan sebanyak tiga kali dan hasil pengujian pada Kontrol tidak dijumpai adanya kematian. 


\section{Uji Toksisitas Akut pada $D$. rerio}

Metode uji toksisitas akut seperti yang dideskripsikan oleh OECD No. 203 tahun 1992 untuk fish, acute toxicity test dengan sedikit modifikasi. Penelitian ini menggunakan $D$. rerio yang berasal dari Laboratorium Farmakologi Fakultas Kedokteran Universitas Mulawarman. D. rerio yang digunakan berumur sekitar 3 bulan dengan panjang $2 \pm 1 \mathrm{~cm}$ dan dipelihara dengan pemberian makan artemia setiap hari, suhu termostat $26^{\circ} \mathrm{C}$ dan $\mathrm{pH}$ air 7,0 dalam ruangan dipertahankan pada suhu $24-26^{\circ} \mathrm{C}$ dengan siklus terang gelap secara alami, aerasi secara kontinue dengan pompa dengan kadar oksigen $>60 \%$. Ekstrak dengan berbagai konsentrasi $(100,250$, 500, 750, 1000, 1500 dan $2000 \mathrm{mg} / \mathrm{L})$ dan Kontrol (pelarut ekstrak DMSO 0,01\%), dimasukkan 7 ekor ikan dan diamati jumlah kematian pada jam ke-24, 48, 72, dan 96, lalu dihitung nilai $\mathrm{LC}_{50}$ dengan menggunakan program Probit. Pengulangan dilakukan sebanyak tiga kali dan hasil pengujian pada Kontrol tidak dijumpai adanya kematian.

\section{Analisis Data}

Semua data toksisitas pada uji imobilisasi $D$. magna dan uji toksisitas akut $D$. rerio disajikan dalam bentuk nilai mean \pm SD. Nilai $\mathrm{LC}_{50}$ dihitung dengan menggunakan program probit dari EPA Probit ver. 1,5. Nilai $\mathrm{LC}_{50}$ dengan program Probit dihitung dengan menggunakan lima konsentrasi.

\section{Hasil dan Pembahasan}

\section{Ekstraksi daun A. papuana}

Daun A. papuana yang telah dikeringkan dengan kadar air 9,5\% seperti yang dipersyaratkan oleh Farmakope Herbal Indonesia (2008), diekstraksi dengan pelarut etanol 97\% secara maserasi. Melalui hasil ekstraksi didapatkan rendemen sebesar $10,49 \%$ dengan kadar air ekstrak sebesar 11,71\%. Kadar air $<10 \%$ untuk simplisia kering diperlukan agar dapat disimpan dalam jangka waktu lama.

\section{Uji imobilisasi $D$. magna}

D. magna termasuk keluarga dari Daphmiidae atau sering disebut sebagai water flea (kutu air). Ia termasuk subphyllum
Crustaceae yang berukuran kecil yang hidup di perairan tawar yang sudah digunakan secara luas dalam beberapa tahun terakhir ini untuk pengujian toksisitas pada obat dan pencemaran lingkungan serta kelainan morfologi pada embrio yang ditimbulkannya setelah pajanan bahan kimia. Ia memiliki kelebihan karena yang betina dapat bereproduksi secara parthenogenetik artinya dapat bertelur dan menjadi anakan tanpa perlu pejantan dan dapat juga secara seksual tergantung kondisi lingkungan. Ukurannya antara 1-3 mm, ciri khasnya adalah memiliki tubuh yang pipih, kulit tubuh bagian punggung membentuk suatu lipatan yang menutupi bagian tubuh beserta anggota tubuhnya pada kedua belah sisi sehingga terlihat seperti cangkang.

Pada habitat aslinya, ia bereproduksi secara parthenogenesis dan seksual. Pada perkembangan secara parthenogenesis, ia hanya menghasilkan individu betina dan dihasilkan telur sebanyak 2 - 40 buah, dalam lingkungan yang normal perkembangan pathenogenesis lebih sering terjadi (Pennak, 1989). Telur-telur disimpan dalam tubuh yaitu di ruangan penetasan dan berkembang sampai menetas menjadi individu betina. Individu yang dihasilkan ini mempunyai bentuk yang serupa dengan induknya dengan ukuran yang lebih kecil dan dikeluarkan dari ruang penetasan pada saat induknya mengalami pergantian kulit (Kusumaryanto, 1988).

Umur D. magna dapat mencapai 31 hari pada suhu lingkungan yang berkisar $24-28^{\circ} \mathrm{C}$. Dalam dua hari ia dapat menghasilkan anakan sebanyak 29 ekor tergantung kondisi lingkungan. Selama hidupnya dapat berkembang biak sebanyak tujuh kali dengan jumlah total keturunan dapat mencapai 200 ekor. Selama hidupnya ia mengalami 4 periode, yaitu telur, juvenil, remaja dan dewasa. Segmentasi mulai terjadi setelah telur dilepaskan ke kantung induk (brood chamber), setelah kurang lebih dua hari instar juvenil pertama yang bentuknya mirip dewasa dilepas dari kantung induknya.

Penelitian uji toksisitas ini menggunakan D. magna yang berusia <24 jam yang didapatkan dari indukan $D$. magna yang mengandung telur, kemudian dipajan dengan ekstrak etanol $A$. papuana dengan berbagai konsentrasi, lalu pada 24 dan 48 jam diamati berapa jumlah D. magna yang tidak bergerak dan dianggap sudah mati. 
Uji toksisitas dilakukan dengan pengamatan efek suatu zat pada hewan uji, dapat berupa kematian dan imobilisasi atau ketidakmampuan untuk bergerak, sehingga uji toksisitas dapat dilakukan dengan uji lethalitas dan uji imobilisasi, tergantung pada hewan uji yang digunakan (Frank, 1995). Pada uji imobilisasi akut, berbagai konsentrasi zat yang diujikan akan menghasilkan berbagai tingkat efek toksik yang berkolerasi dengan kemampuan berenang hewan uji larva $D$. magna yang dalam penelitian ini diamati dalam 48 jam paparan seperti yang dideskripsikan oleh OECD (1984). Sesuai dengan kesepakatan OECD (1984), imobilisasi adalah suatu keadaan organisme atau hewan yang tidak mampu untuk bergerak aktif atau berenang kembali dalam 15 detik setelah pengadukan ringan pada tabung uji setelah perlakuan selama 48 jam.

Tabel 1. Jumlah kematian D. magna dan nilai $\mathrm{LC}_{50}$ setelah perlakuan ekstrak etanol daun A. papuana dengan berbagai konsentrasi pada 24 dan 48 jam

\begin{tabular}{llllll}
\hline & \multirow{2}{*}{ Konsentrasi (mg/L) } & \multicolumn{4}{c}{ Lama Perlakuan } \\
\cline { 2 - 6 } & \multicolumn{3}{c}{ 24 Jam } & \multicolumn{3}{c}{ 48 Jam } \\
\cline { 2 - 5 } & Mean & \pm & SD & Mean & \pm SD \\
\hline \hline 10 & 0,0 & $\pm 0,0$ & 2,7 & $\pm 0,6$ \\
50 & 1,0 & $\pm 1,0$ & 3,7 & $\pm 0,6$ \\
100 & 2,7 & $\pm 0,6$ & 6,7 & $\pm 1,5$ \\
250 & 5,3 & $\pm 1,5$ & 8,7 & $\pm 0,6$ \\
500 & 10,0 & $\pm 0,0$ & 10,0 & $\pm 0,0$ \\
\hline \hline Nilai LC5 & 170 & \pm 28 & 45 & \pm 9 \\
\hline
\end{tabular}

Keterangan: $\mathrm{n}=3$ kali pengulangan. Larva $D$. magna yang digunakan 10 ekor pada tiap konsentrasi.

Tabel 2. Skala toksisitas akut berdasarkan Fish and Wildlife Servis

\begin{tabular}{cc}
\hline \hline Relative toxicity & Aquatic $\boldsymbol{L C}_{\boldsymbol{5} \boldsymbol{0}}(\boldsymbol{m g} / \mathbf{L})$ \\
\hline \hline Super toxic & $0,01-0,1$ \\
Highly toxic & $0,1-1$ \\
Moderately toxic & $1-10$ \\
Slightly toxic & $10-100$ \\
Practically non-toxic & $100-1000$ \\
Relatively harmless & $>1000$ \\
\hline \hline
\end{tabular}

Pada konsentrasi $10 \mathrm{mg} / \mathrm{L}$ semua $D$. magna tidak ada yang mati pada perlakuan selama 24 jam, tetapi mulai ada yang mati pada perlakuan selama 48 jam pada konsentrasi yang sama. Peningkatan konsentrasi dan lama waktu perlakuan akan meningkatkan jumlah yang mati. Pada konsentrasi $500 \mathrm{mg} / \mathrm{L}$ semua D. magna mati pada perlakuan selama 24 dan 48 jam, seperti pada Tabel 1. Hasil perhitungan nilai $\mathrm{LC}_{50}$, didapatkan nilai $\mathrm{LC}_{50}$ ekstrak etanol daun A. papuana adalah $(170+28) \mathrm{mg} / \mathrm{L}$ untuk 24 jam dan $(45 \pm 9) \mathrm{mg} / \mathrm{L}$ untuk 48 jam. Sesuai skala toksisitas akut berdasarkan nilai $\mathrm{LC}_{50}$ aquatik dari US Fish and Wildlife Servis pada Tabel 2 (Waynon dan Finley, 1980), ektrak etanol A. papuana termasuk sedikit toksik karena berada antara rentang $(10-100 \mathrm{mg} / \mathrm{L})$ untuk nilai $\mathrm{LC}_{50}$ pada pengamatan 48 jam sehingga dapat diperkirakan memiliki aktivitas sebagai antikanker. Daun A. papuana sudah diteliti memiliki aktivitas sitotoksik terhadap sel line kanker payudara T47D dan sel Vero (Maritsa dkk., 2015; Kristiani dkk., 2016). Atas dasar penelitian di atas maka penggunaan daun $A$. papuana harus hati-hati terutama dosis besar dan wanita hamil karena berpotensi sitotoksik sehingga diperlukan penelitian lebih lanjut mencakup uji toksisitas subakut, kronik dan embriotoksik. 


\section{Uji Toksisitas D. rerio}

D. rerio dalam perdagangan ikan hias lebih akrab dengan sebutan ikan zebra atau zebrafish. Ikan ini sangat populer dikalangan hobi ikan hias karena warnanya yang menarik dan harganya yang murah. Warnanya sangat cantik dengan warna dasar emas atau perak, dengan garis horisontal yang membentang dari insang hingga ke ujung ekor. Warna garis-garis ini ada yang biru juga ada yang ungu. Untuk ikan jantan postur tubuhnya lebih torpedo, sedangkan untuk betina perutnya lebih besar. Panjang maksimal ikan ini adalah $5 \mathrm{~cm}$. Sedangkan untuk umur, pada umumnya hanya dua tahun, terkadang juga hingga lima tahun.
D. rerio termasuk ikan yang mudah dipelihara, bahkan untuk pemula, karena ikan ini toleran dengan berbagai parameter air. D. rerio akan lebih baik jika dirawat dengan berkelompok, dianjurkan untuk merawat $D$. rerio minimal enam ekor per akuarium. Pada penelitian ini digunakan tujuh ekor ikan seperti yang dideskripsikan dalam protokol OECD (2004). Pakan untuk hewan ini sangat mudah, karena termasuk omnivore, apapun yang diberikan, mulai dari pakan serpihan, pakan beku atau pakan hidup seperti misalnya cacing darah, kutu air dan udang laut akan dimakan olehnya (McGrath, 2002; Detrich dkk., 2004; William, 2017).

Tabel 3. Jumlah kematian $D$. rerio dan nilai $\mathrm{LC}_{50}$ setelah perlakuan ekstrak etanol daun A. papuana pada $24,48,72$, dan 96 jam dengan berbagai konsentrasi

\begin{tabular}{|c|c|c|c|c|c|c|c|c|c|c|c|c|}
\hline \multirow{3}{*}{$\begin{array}{c}\text { Konsentrasi } \\
\quad(\mathrm{mg} / \mathrm{L})\end{array}$} & \multicolumn{12}{|c|}{ Lama Perlakuan } \\
\hline & \multicolumn{3}{|c|}{24 Jam } & \multicolumn{3}{|c|}{ 48 Jam } & \multicolumn{3}{|c|}{72 Jam } & \multicolumn{3}{|c|}{96 Jam } \\
\hline & Mean & \pm & SD & Mean & \pm & SD & Mean & \pm & SD & Mean & \pm & SD \\
\hline 100 & 0,0 & \pm & 0,0 & 0,0 & \pm & 0,0 & 0,3 & \pm & 0,6 & 0,7 & \pm & 0,6 \\
\hline 250 & 0,0 & \pm & 0,0 & 0,7 & \pm & 0,6 & 1,3 & \pm & 0,6 & 1,7 & \pm & 0,6 \\
\hline 500 & 0,3 & \pm & 0,6 & 1,3 & \pm & 0,6 & 2,3 & \pm & 0,6 & 3,3 & \pm & 0,6 \\
\hline 750 & 2,3 & \pm & 0,6 & 3,3 & \pm & 0,6 & 4,3 & \pm & 0,6 & 5,7 & \pm & 0,6 \\
\hline 1000 & 5,3 & \pm & 0,6 & 6,3 & \pm & 0,6 & 7,0 & \pm & 0,0 & 7,0 & \pm & 0,0 \\
\hline 1500 & 6,3 & \pm & 0,6 & 7,0 & \pm & 0,0 & 7,0 & \pm & 0,0 & 7,0 & \pm & 0,0 \\
\hline 2000 & 7,0 & $\underline{\underline{t}}$ & 0,0 & 7,0 & $\underline{\underline{t}}$ & 0,0 & 7,0 & \pm & 0,0 & 7,0 & \pm & 0,0 \\
\hline Nilai LC $_{50}$ & 855 & \pm & 55 & 670 & \pm & 94 & 504 & \pm & 102 & 393 & \pm & 89 \\
\hline
\end{tabular}

Keterangan: n=tiga kali pengulangan. D. rerio digunakan sebanyak 7 ekor pada tiap konsentrasi

D. rerio yang digunakan pada uji toksisitas akut ekstrak etanol A. papuana adalah ikan dewasa $D$. rerio yang berusia 3 bulan. Perlakuan diberikan selama 96 jam dan diamati setiap 24 jam. Pada konsentrasi 100 mg/mL semua ikan tidak ada yang mati dan ditandai pergerakan yang aktif. Pada konsentrasi ekstrak $2000 \mathrm{mg} / \mathrm{L}$ semua ikan mati yang ditandai dengan ikan mengapung dan pergerakan hilang pada 24 jam setelah perlakuan, sedangkan konsentrasi $1500 \mathrm{mg} / \mathrm{L}$ semua ikan mati pada perlakuan selama 48, dan pada konsentrasi 100 mg/L semua ikan mati pada perlakuan selama 72 dan 96 jam. Pada kontrol tidak dijumpai adanya kematian pada konsentrasi $2000 \mathrm{mg} / \mathrm{L}$. Dari penelitian ini dapat diketahui nilai $\mathrm{LC}_{50} D$. rerio pada perlakuan selama 24, 48, 72 dan 96 jam seperti pada Tabel 3. Pada penelitian ini terlihat bahwa peningkatan konsentrasi dan lama waktu perlakuan akan meningkatkan jumlah ikan $D$. rerio yang mati. Hasil perhitungan nilai $\mathrm{LC}_{50}$ dengan menggunakan program Probit, didapatkan nilai $\mathrm{LC}_{50}$ yang semakin rendah dengan meningkatnya lama waktu perlakuan ekstrak terhadap ikan D. rerio. Sesuai klasifikasi toksisitas berdasarkan nilai $\mathrm{LC}_{50}$ aquatik dari Fish and Wildlife Servise (Waynon dan Finley, 1980), ektrak etanol A. papuana pada D. rerio termasuk tidak toksik karena berada antara rentang (100-1000 mg/L) untuk nilai $\mathrm{LC}_{50}$ pada pengamatan 96 jam. Penelitian ini juga memperlihatkan, ikan $D$. rerio digunakan ikan berumur 3 bulan lebih tahan terhadap toksikan luar dibandingkan D. magna yang berumur 24 
jam, sehingga selain spesies hewan uji kemungkinan umur hewan uji dapat memengaruhi hasil uji toksisitas akut.

Hasil penelitian ini memperlihatkan bahwa semakin lama perlakukan akan semakin rendah nilai $\mathrm{LC}_{50}$ artinya semakin banyak menyebabkan kematian, dan semakin rendah hewan uji yang digunakan untuk uji toksisitas akan semakin rentan, semakin muda hewan uji juga akan semakin rentan. Penelitian ini dapat menjadi dasar untuk penelitian lanjutan dengan menggunakan embrio ikan $D$. rerio. Penelitian ini dapat sebagai dasar untuk penelitian embriotoksik karena $D$. rerio sangat fertil dan ikan betina ini dapat bertelur ratusan setiap minggunya, setelah fertilisasi perkembangannya sangat cepat dari embrio menjadi larva (membutuhkan waktu hanya tiga hari) dan embrio tampak transparan sehingga mudah diamati (Detrich dkk., 2004).

Penelitian ini memperlihatkan juga larva D. magna lebih sensitif untuk uji toksisitas akut dibandingkan ikan D. rerio. Hasil ini memperkuat penelitian Martins dkk. (2007), pada pengujian ekotoksisitas untuk mengevaluasi dan memonitor kualitas air dengan D. magna didapatkan nilai $\mathrm{LC}_{50}$ yang lebih kecil dibandingkan $D$. rerio. D. magna juga telah diketahui lebih sensitif dibandingkan A. salina, seperti pada penelitian Favila dkk. (2006) pada uji toksisitas metabolit jamur didapatkan nilai $\mathrm{LC}_{50}$ yang lebih toksik untuk $D$. magna dibandingkan A. salina. D. magna juga lebih sensitif dibandingkan tikus pada uji toksisitas akut (Guilherminto dkk., 1999). Semua hal tersebut di atas menunjukkan D. magna dapat menjadi model hewan alternatif untuk skrining awal uji toksisitas akut karena sensitivitas yang tinggi. Keunggulan lain adalah murah, lebih mudah dikembangbiakkan dan dipelihara serta siklus hidupnya pendek.

\section{Simpulan dan Saran}

\section{Simpulan}

Ekstrak etanol daun A. papuana relatif toksik terhadap D. magna dengan nilai $\mathrm{LC}_{50}(45$ 土9) $\mathrm{mg} / \mathrm{L}$ pada perlakuan selama 48 jam, tetapi tidak toksik terhadap $D$. rerio terhadap perlakuan selama 96 jam dengan nilai $\operatorname{LC}_{50}(393 \pm 89)$ $\mathrm{mg} / \mathrm{L}$.

\section{Saran}

Penelitian lanjutan diperlukan pada ekstrak etanol daun $A$. papuana dengan menggunakan $D$. magna yang mengandung telur dan embrio $D$. rerio untuk memprediksi efek embriotoksik sebagai salah satu model pengujian keamanan pada penggunaan jangka panjang sebagai bumbu masak.

\section{Ucapan Terima Kasih}

Ucapan terima kasih kepada Direktorat Riset dan Pengabdian Kepada Masyarakat Kementerian Riset, Teknologi dan Pendidikan Tinggi yang telah mendanai penelitian ini melalui Hibah Penelitian Dosen Pemula berdasarkan Surat Keputusan Nomor: 3/E/KTP/2018 dan Perjanjian/Kontrak Nomor: 108/UN17.41/KL/2018.

\section{Daftar Pustaka}

Association of Official Analytical Chemist (AOAC). 2006 Official Method of Analysis of The Association of Official Analytical of Chemist. Arlington (US): AOAC Int.

Departemen Kesehatan Republik Indonesia (Depkes). 2008. Farmakope Herbal Indonesia. Edisi Pertama. Departemen Kesehatan, Direktorat Jenderal Pengawasan Obat dan Makanan, Jakarta.

Departemen Kesehatan Republik Indonesia (Depkes). 1995. Farmakope Indonesia. Edisi ke 4. Departemen Kesehatan, Direktorat Jenderal Pengawasan Obat dan Makanan, Jakarta.

Detrich-III HW, Zon LI, dan Westerfield. 2004. The Zebrafish: Cellular and Developmental Biology: Vol 76 (Methods in Cell Biology) 2nd Edition, Kindle Edition, Publisher: Academic Press.

EPA US (Environmental Protection Agency United States). 1996. Ecological effects test guidelines. OCSPP 850.1010: Aquatic invertebrate acute toxicity test, freshwater Daphnids.

Frank, C. 1995. Toksikologi dasar: asas, organ sasaran, dan penilaian resiko. Edisi 2, Jakarta, UI Press.

Guilherminto, L., Diamantino, T., Silva, M.C., dan Soares, A.M. 1999. Toxicity test with Daphnia magna: an alternative to mammals. Ecotoxicology and Environmental Safety, 46:357-62. 
Hodgson, E., dan Levi, P. 2000. A textbook of modern toxicology. 2nd edition, Singapore, McGrawHill Higher Education.

Ismail, S., Hayati, N., Safitrim Y., Gunawan, Y., Kurniasari, C., Suwasono, R.A., dan Supriyoko, W. 2017. Uji praklinik pada 10 tumbuhan obat yang berkhasiat antihipertensi secara etnobotani untuk pembuktian secara ilmiah hasil Ristoja tahun 2012 dan 2015 di Kaltim dan Kaltara. Badan Penelitian dan Pengembangan Kesehatan Kementerian Kesehatan Republik Indonesia, Balai Besar Penelitian dan Pengembangan Tanaman Obat dan Obat Tradisional dan Lembaga Penelitian dan Pengabdian pada Masyarakat Universitas Mulawarman. Laporan Penelitian.

Kristiani, E.B.A., Pratiwi, R., Ifandari, Zainal, P.F., and Nugroho, L.H. 2016. Sitotoksisitas batang dan daun Albertisia papuana Becc. terhadap sel kanker payudara dan sel kanker rahim. Seminar Nasional Biodiversitas Tropis, FMIPA Universitas Negeri Malang, 10 September 2016.

Lusiana, H., Irawadi, T.T., dan Suparto, I.H. 2013. Uji anti plasmodium senyawa alkaloid dari Albertisia papuana Becc. Prosiding Seminar Nasional Kimia Terapan Indonesia, Solo, 23 Mei 2013, 1:75-8. ISSN: 2088-9828.

Maritsa, H., Moeljopawiro, S., Kasiamdari, R.S. 2015. Sitotoksisitas ekstrak Aspergillus fumigatus dari daun mekai (Arbetisia papuana Becc.) terhadap sel kanker payudara T47D dan MCF-7. BioSite, 1(1): 39-40.

Martins, J., Teles, L.O., dan Vasconcelos, V. 2007. Assay with Daphnia magna and Danio rerio as alert systems in aquatic toxicology. Environ Int., 33(3):414-25.

Martínez-Sales M, García-Ximénez F, Espinós FJ. 2015. Zebrafish as a possible bioindicator of organic pollutants with effects on reproduction in drinking waters. Journal of Environmental Sciences, 33: 254-60.

Mayasari, E., Anandika, O., Saloko, S., dan Ulfa, M. 2017. Pembuatan bumbu instan dari ekstrak daun san-kang (Albertisia papuana Becc.) sebagai alternatif penyedap alami. Seminar Nasional Penerapan Ilmu Pengetahuan dan Teknologi, Universitas Tanjungpura, Pontianak, 23-24 Mei 2017.

McGrath P. 2012. Zebrafish: Methods for Assessing Drug Safety and Toxicity. 1st Edition, Kindle Edition, Penerbit: Wiley.

Nitulescu, G. M., Draghici, C., dan Olaru, O. T. 2013. New potential antitumor pyrazole derivatives: synthesis and cytotoxic evaluation. International journal of molecular sciences, 14(11), 21805-18.
OECD (Organisation for Economic Co-operation and Development). 1984. 202: OECD guideline for testing of chemicals: Daphnia sp., acut immobilisation test and reproduction test.

OECD (Organisation for Economic Co-operation and Development). 1992. 203: OECD guideline for testing of chemicals: Daphnia sp., acut immobilisation test.

OECD (Organisation for Economic Co-operation and Development). 2004. 202: OECD guideline for testing of chemicals: fish, acute toxicity test.

Rubinstein, A.L. 2006. Zebrafish assays for drug toxicity screening. Expert Opin Drug Metab Toxicol, 2(2):231-40

Susiarti, S., dan Setyowati FM. 2005. Bahan rempah tradisional dari masyarakat Dayak Kenyah di Kalimantan Timur. Biodiversitas, 6(4): 285-7.

United States Environmental Protection Agency (US EPA). 1987. EPA/600/8- 87/011/March 1987. Procedures for conducting Daphnia magna toxicity bioassays.

Waynon W.J., dan Finley M.F. 1980. Handbook of Acute Toxicity of Chemicals to Fish and Aquatic Invertebrates. United States Department of the Interior Fish and Wildlife Service, Resources Publication, p. 137. 